\title{
Periodic acid-Schiff reaction and prognosis in lymphoblastic leukaemia
}

\author{
J. S. LilleyMAN, V. Mills, P. J. SUGDEN, AND J. A. BRITTON
}

From the Department of Haematology, Sheffield Children's Hospital, Western Bank, Sheffield S10 2TH, UK

SUMMARY Diagnostic bone marrow smears from 132 patients with acute lymphoblastic leukaemia (ALL) were stained simultaneously by the periodic acid-Schiff (PAS) reaction, and the blast cell positivity was assessed quantitatively.

The patients fell naturally into two unequal groups: those with more than $20 \%$ PAS-positive blast cells (44 patients) and those with less ( 88 patients). There was no relation between the degree of positivity and age, sex, or presenting leucocyte count.

Actuarial survival studies showed that the group with more than $20 \%$ PAS-positive blast cells survived longer, but that this difference assumed statistical significance only after the exclusion of patients over 14 years old and those with high white cell counts at the time of diagnosis.

It appears that the PAS reaction can identify longer survivors among patients with ALL, but only in the absence of features strongly associated with a poor prognosis.

A variable amount and distribution of periodic acid-Schiff (PAS)-positive material in the blast cells of patients with acute lymphoblastic leukaemia (ALL) is well described (Hayhoe et al., 1964). Attempts to correlate the pattern of reaction with prognosis, however, have yielded a conflicting and confusing literature. Some authors suggest that strong PAS-positivity indicates a good prognosis (Laurie, 1968;Vowels and Willoughby, 1973; Feldges et al., 1974; Ascari et al., 1975) but others claim that it has no such significance (Bennett and Henderson 1969; Berrebi et al., 1973; Humphrey et al., 1974; Shaw et al., 1977).

In an attempt to explain this disparity, we have considered the possibility of a genuine PAS effect being masked by stronger, adverse influences on prognosis. For this reason we assembled a large group of unselected patients with ALL, studied the PAS pattern and survival, and reviewed this in the light of age and white cell count at diagnosis.

\section{Patients and methods}

The patients described were seen at the Sheffield Children's Hospital or the Sheffield Royal Infirmary between January 1970 and January 1978. Lympho-

Received for publication 31 July 1978 blastic leukaemia was diagnosed on conventional clinical, morphological, and cytochemical grounds, and initially combination chemotherapy was given according to the relevant United Kingdom Medical Research Council therapeutic trial of the time, whether the patients were actually in such a trial or not.

Romanowsky-stained diagnostic bone marrow smears were gathered together and subjected to the PAS reaction according to the method described by Hayhoe et al. (1960). All were so treated in one batch on the same day with one collection of freshly prepared reagents.

Two observers assessed the PAS reaction product in all cases by each counting one thousand blast cells on each slide. Results were recorded both as a percentage of such cells showing any PAS-positivity at all and as a composite score devised by Hayhoe et al. (1964). Slides were coded by a number rather than a patient's name to avoid possible bias by knowledge of the clinical course of a given patient.

Results were stratified and correlated with survival using the life table and logrank significance assessment methods described by Peto et al. (1977). The absence of any significant excess of patients with high presenting white cell counts $\left(>20.0 \times 10^{9} / 1\right)$, or those over 14 years old, or males in any of the PAS-defined 'strata, was checked by chi-square analysis. 


\section{Results}

During the study period 132 patients with ALL were seen; 100 were children under 14 years of age, and 89 presented with a leucocyte count below $20.0 \times 10^{9} / 1$. All were caucasian and 77 were male.

PAS studies on diagnostic blast cells showed that 35 patients had no PAS-positive material at all, 45 had less than $10 \%$ positive blasts, 8 had $10 \%$ to $20 \%, 22$ had $20 \%$ to $40 \%$, and 22 had over $40 \%$. The patients were easily and naturally divided into two unequal groups with more or less than $20 \%$ positive blasts, and these are shown alongside the presenting leucocyte count, age, and sex in the Table.

The use of the percentage of blast cells showing PAS-positivity, as opposed to a composite score suggested by Hayhoe et al. (1964), was arbitrary, as near perfect correlation between the two methods of assessment in this study was achieved by biind comparison.

Examining the survival of all patients with ALL in the two strata defined (those with $<20 \%$ PASpositive cells (group A), and those with $>20 \%$ PAS-positive cells (group B)), there was a longer median survival in group B (Fig. 1) but this was not statistically significant.

By extraction of patients with one of two criteria of poor-prognosis disease (age over 14 years or presenting leucocyte count $>20.0 \times 10^{9} / 1$ ), the difference between the group $A$ remainder and the group B remainder was statistically significant (Fig. 2) to the level of $P<0.02$.

There was no correlation between the percentage of PAS-positive cells and any other prognostic feature, that is, there was no excess of adults, males, or high presenting leucocyte counts in either of the PAS defined groups.

\section{Discussion}

It is well known that patients with ALL are a heterogeneous group, some of whom can be prospectively identified as carrying a worse prognosis. High $\left(>20.0 \times 10^{9} / 1\right)$ presenting leucocyte counts, an age at diagnosis of much over 10 years, and negro descent have been recognised as features having sinister significance in this respect for some time (Kay, 1974).

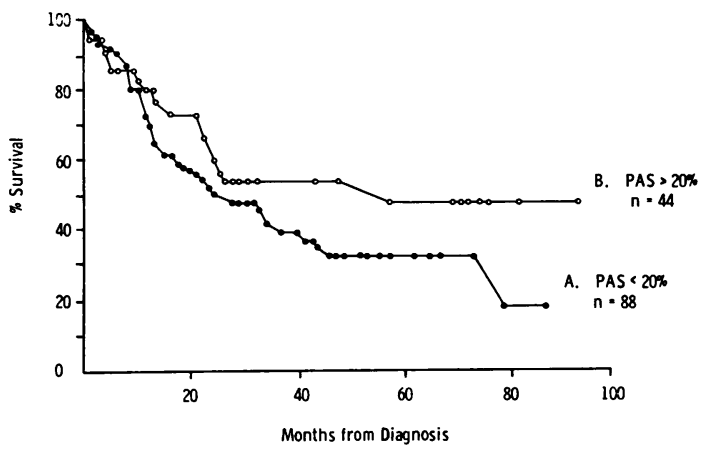

Fig. 1 Life table survival analysis on patients with $A L L$. Group A: $<20 \%$ PAS-positive blast cells at diagnosis, group B: $>20 \%$ PAS-positive blast cells at diagnosis. Difference not significant (logrank test).



Fig. 2 Life table survival analysis on patients with $A L L$ aged $<14$ yr and with leucocyte counts on presentation $<20.0 \times 10^{\circ} / \mathrm{l}$. Group A: $<20 \%$ PAS-positive blasts at diagnosis; group $B:>20 \% P A S$-positive blasts at diagnosis. Difference significant, $\mathrm{P}<0.02$ (logrank test).

More recently, the possession of $\mathbf{T}$ or B cell surface markers (Chessells et al., 1977) or merely being male (Baumer and Mott, 1978) have emerged as further indicators of a poor outlook.

In contrast, attempts to attach benign prognostic significance to the PAS reaction of the blast cells at diagnosis have given conflicting results, some claiming there to be no significance (Bennett and Henderson, 1969; Berrebi et al., 1973; Humphrey

Table PAS-positivity and known prognostic factors

\begin{tabular}{|c|c|c|c|c|c|c|}
\hline \multirow[t]{2}{*}{$P A S$-positive cells $\%$} & \multirow[t]{2}{*}{ Total } & \multicolumn{2}{|c|}{ Age $(y r)$} & \multicolumn{2}{|c|}{ Presenting $W C C\left(\times 10^{\circ} / l\right)$} & \multirow[t]{2}{*}{ Males } \\
\hline & & $>14$ & $<14$ & $>20 \cdot 0$ & $<20 \cdot 0$ & \\
\hline $\begin{array}{l}<20(\text { group A) } \\
>20(\text { group B })\end{array}$ & $\begin{array}{l}88 \\
44\end{array}$ & $\begin{array}{l}22 \\
10\end{array}$ & $\begin{array}{l}66 \\
34\end{array}$ & $\begin{array}{l}32 \\
11\end{array}$ & $\begin{array}{l}56 \\
33\end{array}$ & $\begin{array}{l}51 \\
26\end{array}$ \\
\hline
\end{tabular}


et al., 1974; Shaw et al., 1977) and others suggesting that PAS-positive cells are increased in patients with less aggressive disease (Laurie, 1968; Vowels and Willoughby, 1973; Feldges et al., 1974; Ascari et al., 1975).

This confusion over the significance of the PAS reaction could be due to at least two causes. First, no published series has taken into account the potential interaction of conflicting prognostic features, and, with small numbers, an excess of patients with high white cell counts or other variety of poor-prognosis ALL could mask any PAS effect that might otherwise be apparent. Secondly, the technique of actually performing a PAS stain is subject to day-to-day variation, even in experienced hands, and the significance of moderate differences in a quantitative assessment of two such stains could be open to question if they are performed at different times with different reagents. We attempted to overcome these two problems by assembling a larger group of patients than has previously been reported and were able to stain the diagnostic marrow slides all together at the same time, as the PAS reaction can be satisfactorily carried out on previously Romanowsky-stained films that are up to 10 years old (Hayhoe et al., 1960).

From the results we obtained it seems that the PAS reaction can identify potentially longer surviving patients, but even in a series of this size the effect is apparent only in the absence of stronger, adverse influences on prognosis, that is, a high presenting leucocyte count and older age.

Whether other accepted poor-prognosis features can similarly modify this PAS effect is not so clear. Membrane marker studies were not performed on the earlier patients in this study, so it is not possible to assess how, for example, T-cell disease relates to the PAS reaction. Those later patients who were known to have T-ALL in our series (five in all) had a widely variable percentage of PAS-positive blasts, but all had white cell counts over $20.0 \times 10^{9} / 1$ and were excluded for that reason from the patient groups represented in Figure 2.

Furthermore, it is not possible to comment on whether the PAS effect is influenced by sex, and although we have shown a significant survival advantage for both sexes in group B in Fig. 2, it may be that this would be more clear if only females were considered. Unfortunately, too few patients were available for such an analysis to be reliable, so this question cannot be answered.

That the PAS reaction might identify a specific sub-variety of ALL is worth consideration. Probably it does not, as all degrees of positivity can be found in all varieties of the disease, despite the fact that in most cases blast cells tend to be either nearly all negative or more than $20 \%$ positive. It is perhaps more likely that a PAS-positive blast cell might indicate a particularly treatment-sensitive degree of biochemical differentiation, and it would be of interest to follow the PAS reaction through the various stages of a number of patients with relapsing ALL to see if increasing resistance to chemotherapy is marked by a loss of PAS-positive cells where these were present initially, although Berrebi et al. (1973) have indicated that this might not be so. We are currently examining this point further.

This work was supported by a grant from the Trent Regional Health Authority.

\section{References}

Ascari, E., Marini, G., Invernizzi, R., Ippolita, G., Casirola, G., Fontana, G., and Rizzo, S. C. (1975). On the usefulness of PAS reaction for the prognosis of acute lymphoblastic leukemia. Haematologica, 60, 300-307.

Baumer, J. H., and Mott, M. G. (1978). Sex and prognosis in childhood acute lymphoblastic leukaemia. Lancet, 2, 128-129.

Bennett, J. M., and Henderson, E. S. (1969). Lymphoblastic leukaemia (letter). British Medical Journal, 2, 513.

Berrebi, A., Malaskova, V., Oberling, F., and Mayer, S. (1973). Application des techniques cytochimiques à 47 cas de leucémies aiguës: modifications cytochimiques au cours de l'évolution. Semaine des Hôpitaux de Paris, 49, 633-643.

Chessells, J. M., Hardisty, R. M., Rapson, N. T., and Greaves, M. F. (1977). Acute lymphoblastic leukaemia in children: classification and prognosis. Lancet, 2 , 1307-1309.

Feldges, A. J., Aur, R. J. A. Verzosa, M. S., and Daniels, S. (1974). Periodic acid-Schiff reaction, a useful index of duration of complete remission in acute childhood lymphocytic leukemia. Acta Haematologica, 52, 8-13.

Hayhoe, F. G. J., Quaglino, D., and Doll, R. (1964). The cytology and cytochemistry of acute leukaemias. Special Report Series, Medical Research Council, 304.

Hayhoe, F. G., J. Quaglino, D., and Flemans, R. J. (1960). Consecutive use of Romanowsky and periodicacid-Schiff techniques in the study of blood and bonemarrow cells. British Journal of Haematology, 6, 23-25.

Humphrey, G. B., Nesbit, M. E., and Brunning, R. D. (1974). Prognostic value of the periodic acid-Schiff (PAS) reaction in acute lymphoblastic leukemia. American Journal of Clinical Pathology, 61, 393-397.

Kay, H. E. M. (1974). The acute leukaemias. In Blood and its Disorders, edited by R. M. Hardisty and D. J. Weatherall, p. 942. Blackwell, Oxford.

Laurie, H. C. (1968). Duration of remissions in lymphoblastic leukaemia of childhood. British Medical Journal, 2, 95-97. 
Peto, R., Pike, M. C., Armitage, P., Breslow, N. E., Cox, D. R., Howard, S. V., Mantel, N., McPherson, K., Peto, J., and Smith, P. G. (1977). Design and analysis of randomised clinical trials requiring prolonged observation of each patient. II. Analysis and examples. British Journal of Cancer, 35, 1-39.

Shaw, M. T., Humphrey, G. B., Lawrence, R., and Fischer, D. B. (1977). Lack of prognostic value of the periodic acid-Schiff reaction and blast cell size in childhood acute lymphocytic leukemia. American
Journal of Hematology, 2, 237-243.

Vowels, M. R., and Willoughby, M. L. N. (1973). Cyclic chemotherapy in acute lymphoblastic leukaemia of childhood: 5-year survivals. Archives of Disease in Childhood, 48, 436-440.

Requests for reprints to: Dr J. S. Lilleyman, Department of Haematology, The Children's Hospital, Western Bank, Sheffield, S10 2TH, UK.

\section{Reports and Bulletins prepared by the Association of Clinical Biochemists}

The following reports and bulletins are published by the Association of Clinical Biochemists. They may be obtained from The Publishing Department, British Medical Journal (ACB Technical Bulletins), B.M.A. House, Tavistock Square, London WC1H 9JR. Overseas readers should remit by British Postal or Money Order.

SCIENTIFIC REVIEWS (price $£ 1 \cdot 00 / \$ 2.00$ each)

1 The assessment of thyroid function March 1971 F. V. FLYNN and J. R. HOBBS

2 Renal function tests suitable for clinical practice January 1972 F. L. MTCHELL, N. VEALL, and R. W. E. WATTS

3 Biochemical tests for the assessment of fetoplacental function May 1975 C. E. WILDE and R. E. OAKEY

4 Test of exocrine pancreatic function March 1977 A. H. GOWENLOCK

TECHNICAL BULLETINS (price $£ 1 \cdot 00 / \$ 2.00$ each)

22 Bilirubin standards and the determination of bilirubin by manual and technicon AutoAnalyzer methods January 1971 BARBARA BILLING, RUTH HASLAM, and $\mathrm{N}$. WALD

23 Interchangeable cells for spectrophotometers and fluorimeters September 1971 S. S. BROWN and A. H. GOWENLOCK

24 Simple tests to detect poisons March 1972 B. w. MEADE et al.

25 Blood gas analysers May 1972 K. DIxON

26 Kits for enzyme activity determination September 1972 S. B. ROSALKI and D. TARLOW

27 Assessment of pumps suitable for incorporation into existing continuous flow analytical systems November 1972 A. FLECK et al.
28 Routine clinical measurements of transferrin in human serum September 1973 K. DIXON

29 Control materials for clinical biochemistry (5th edition) September 1973 J. F. STEVENS

30 Notes on the quality of performance of serum cholesterol assays September 1973 s. s. BROWN

31 Determination of uric acid in blood and in urine July 1974 R. W. E. WATTS

32 A survey of amino acid analysers readily available in the United Kingdom September 1974 J. E. CARLYLE and P. PURKISS

33 Definitions of some words and terms used in automated analysis November 1974 A. FLECK, R. ROBINSON, S. S. BROWN, and J. R. HOBBS

34 Measurement of albumin in the sera of patients January 1975 LINDA SLATER, P. M. CARTER, and J. R. HOBBS

35 Investigation of the validity of temperature correction factors for serum aspartate and alanine transaminases March 1975 s. B. ROSALKI et al.

36 Factors influencing the assay of creatinine November 1975 J. G. H. COOK

37 A survey of enzyme reaction rate analysers readily available in the United Kingdom July 1977 R. A. SAUNDERS and R. F. BURNS

38 Transport of specimens for clinical chemistry analysis November 1977 P. WILDING, J. F. ZILVA, and c. E. WILDE

39 A scheme for the evaluation of diagnostic kits May 1978 P. H. LLOYD 